Brazilian Journal
of Chemical
Engineering

\title{
PHYSICO-CHEMICAL, SPECTROSCOPICAL AND THERMAL CHARACTERIZATION OF BIODIESEL OBTAINED BY ENZYMATIC ROUTE AS A TOOL TO SELECT THE MOST EFFICIENT IMMOBILIZED LIPASE
}

\author{
G. A. M. Silva ${ }^{1}$, P. C. M. Da Rós, L. T. A. Souza, A. P. O. Costa and H. F. de Castro* \\ Engineering School of Lorena, University of São Paulo, PO Box 116 -12602-810, Lorena - SP, Brazil. \\ E-mail: heizir@dequi.eel.usp.br \\ ${ }^{1}$ Current Address: Cooperbio/ MT, Av. Z. s/n, Quadra 09/01, Distrito Industrial, \\ CEP: 78.098-530, Cuiabá - MT, Brasil. \\ E-mail: guilherme@cooperbio.coop.br
}

(Submitted: March 9, 2011 ; Revised: August 8, 2011 ; Accepted: October 20, 2011)

\begin{abstract}
Two microbial lipases from Burkholderia cepacia and Pseudomonas fluorescens were evaluated as catalysts for the enzymatic transesterification of beef tallow with ethanol and the most efficient lipase source was selected by taking into account the properties of the product to be used as fuel. Both lipases were immobilized on an epoxy silica-polyvinyl alcohol composite by covalent immobilization and used to perform the reactions under the following operational conditions: beef tallow-to-ethanol molar ratio of $1: 9,45^{\circ} \mathrm{C}$ and 400 units of enzymatic activity per gram of fat. Products, characterized using Fourier Transform Infrared spectroscopy (FTIR), viscosimetry, thermogravimetry and ${ }^{1} \mathrm{H}$ NMR spectroscopy, suggested that the biodiesel sample obtained in the reaction catalyzed by Burkholderia cepacia lipase has the best set of properties for fuel usage.

Keywords: Biodiesel; Beef tallow; Ethanol route; Immobilized lipase; Thermogravimetric; Rheological properties.
\end{abstract}

\section{INTRODUCTION}

The monoalkyl esters of fatty acids (biodiesel) can be considered to be a green fuel because of their renewable sources and are therefore potential substitutes for diesel from petroleum. These esters are prepared from triglyceride-based feedstocks by transesterification reactions using short chain alcohols (Knothe et al., 2006; Vasudevan and Briggs, 2008).

As biodiesel becomes an increasingly important source of fuel in the world, the search for low cost lipidic raw material sources, and economically feasible routes that can be used to produce this renewable fuel has increased (Hass, 2005). In many countries, several non-edible raw materials have been studied in order to met projected growth in biodiesel production; reduce the competition between food and fuels; lower fuel costs; reduce or eliminate subsidies; bring all available lipid streams into the renewable fuels pool and minimize increases in edible oil prices resulting from their diversion to fuel usage (Vasudevan and Briggs, 2008). One of these is beef tallow, that, besides being a non-edible raw material of low cost, has an excellent availability due to the high production of bovine meat ( $\mathrm{Da}$ Cunha et al., 2009). Therefore, combining the advantages of

*To whom correspondence should be addressed 
sustainability, beef tallow becomes a second source of raw material to produce biodiesel in many countries, including Brazil (Duarte, 2009; Araujo et al., 2010). Regarding the availability of this raw material, Brazil alone produce around 600 thousand tons/ year, being, therefore, a maintainable source for the production of biodiesel and further resulting in a reduction of the pollution impact of that by-product (Duarte, 2009; Da Cunha et al., 2009).

Commercially, biodiesel has been produced by chemical processes that are efficient in terms of reaction time and high yields but have drawbacks in terms of the recovery of glycerol, removal requirement of salt residues, a large amount of wastewater, and high energy costs (Pinto et al., 2005; Helwani et al., 2009). To overcome these drawbacks, the utilization of heterogeneous catalysts, including immobilized lipases to synthesize biodiesel by alcoholysis of triacylglycerols with short-chain alcohols under mild conditions, has attracted considerable attention in recent years (Helwani et al., 2009; Kiss et al., 2010; Muthu et al., 2010). In addition, the use of immobilized lipases in biodiesel production tolerates the water content of the oil and increases biodiesel yield by avoiding soap formation (Ranganathan et al., 2008; Tan et al., 2010; Ghaly et al., 2010).

In this work, attention was paid to study the enzymatic transesterification of beef tallow. The alcohol chosen to carry out the reaction was ethanol, using lipases immobilized on a non-commercial matrix as catalysts. Ethanol reacts at a slower rate than methanol, but it is preferred for the enzymatic process since it is non-toxic and safer to handle and store. In addition, it is a larger and heavier alcohol than methanol, which means a mass yield gain of the biodiesel (Kiss et al., 2010). Ethanol has received less attention than methanol in transesterification processes. There are few papers dealing with transesterification in which ethanol is included in order to compare the behavior with methanol (Kiss et al., 2010). However, the use of ethanol has recently received more attention, presumably because it has a renewable source (Moreira et al., 2007; Bouaid et al., 2009; Da Rós et al., 2010).

Burkholderia cepacia and Pseudomonas fluorescens lipases immobilized on epoxy silicapolyvinyl alcohol $\left(\mathrm{SiO}_{2}\right.$-PVA) composite were chosen based on their suitability for many biotransformation applications and, in particular, for biodiesel enzymatic synthesis (Moreira et al., 2007; Freitas et al., 2009; Da Rós et al., 2010). In addition to the conventional methods of analysis, information on the quality of the biodiesel samples obtained by ${ }^{1} \mathrm{H}$ NMR, thermogravimetry and Fourier transform infrared spectroscopy (FTIR) help to attest to the efficiency of the transesterification reaction and to select the immobilized derivative that gave biodiesel samples with properties in accordance with standard specifications for biodiesel.

\section{EXPERIMENTAL}

\section{Materials}

Two commercial lipases Burkholderia cepacia (Lipase PS) and Pseudomonas fluorescens (Lipase AK) from Amano Pharmaceuticals (Nagoya, Japan) in a crude form were used in this study without further purification. Tetraethoxysilane (TEOS) was acquired from Aldrich Chemical Co. (Milwaukee, WI, USA). Epichlorohydrin, hydrochloric acid (minimum 36\%), ethanol (minimum 99\%), polyvinyl alcohol (molecular weight 72,000) and polyethylene glycol (molecular weight 1,500) were supplied by Reagen (RJ, Brazil). Beef tallow was supplied by Fertibom (Catanduva, SP, Brazil) having the following composition of fatty acids: (w/w): $3 \%$ myristic, $25 \%$ palmitic, $32 \%$ stearic and $40 \%$ oleic with average molecular weight $856.76 \mathrm{~g} \mathrm{~mol}^{-1}$. Solvents were of standard laboratory grade (Synth, SP, Brazil). All the other reagents were of analytical grade.

\section{Support Synthesis and Lipase Immobilization}

The $\mathrm{SiO}_{2}$-PVA composite was prepared by the hydrolysis and polycondensation of tetraethoxysilane according to the methodology previously described (Santos et al., 2008), obtaining particles with the following properties: average pore diameter (22.91 $\AA$ ); surface area BET $\left(461.00 \mathrm{~m}^{2} . \mathrm{g}^{1}\right)$ and porous volume $\left(0.275 \mathrm{~cm}^{3} \cdot \mathrm{g}^{-1}\right)$. Activation of $\mathrm{SiO}_{2}$-PVA particles was carried out with $2.5 \%(\mathrm{w} / \mathrm{v})$ epichlorohydrin, $\mathrm{pH} 7.0$, for $1 \mathrm{~h}$ at room temperature, followed by exhaustive washings with distilled water. Epoxy $\mathrm{SiO}_{2}$-PVA particles were soaked in hexane under stirring (100 rpm) for $1 \mathrm{~h}$ at $25^{\circ} \mathrm{C}$. Then, excess hexane was removed and lipase was added at a ratio of 1:4 gram of enzyme per gram of support. PEG-1500 was added together with the enzyme solution at a fixed amount (5 mg.g $\mathrm{g}^{-1}$ support). The lipase-support system was maintained in contact for $16 \mathrm{~h}$ at $4^{\circ} \mathrm{C}$ under static conditions. The immobilized lipase derivatives were filtered (62HD nylon membrane from Scheiz Seidengazefabrik AG, Thal Schweiz, Switzerland) and thoroughly rinsed with hexane. The hydrolytic activities of the resulting immobilized derivatives were similar and varied in the range from 1600-1800 U.g ${ }^{-1}$ according to the methodology 
previously described (Soares et al., 1999). The biochemical, kinetic properties, thermal stability and operational stability of these immobilized lipase preparations are described elsewhere (Santos et al., 2008, Da Ros et al., 2010).

\section{Biodiesel Synthesis}

The reactions were performed in a jacketed cylindrical glass reactor $(6 \mathrm{~cm}$ high X $4 \mathrm{~cm}$ internal diameter, with a capacity of $100 \mathrm{~mL}$ ) containing $30 \mathrm{~g}$ of substrate consisting of a beef tallow-to-ethanol molar ratio of 1:9, without the addition of solvents. Mixtures were incubated with either lipase PS or AK immobilized on epoxy $\mathrm{SiO}_{2}$-PVA at the fixed proportion of 400 units of hydrolytic activity per gram of beef tallow at $45^{\circ} \mathrm{C}$. Reactions were performed for a maximum period of $48 \mathrm{~h}$ under constant magnetic agitation of $150 \mathrm{rpm}$.

\section{Ethyl Esters Analysis}

Ethyl esters derived from ethanolysis of beef tallow were analyzed by gas chromatography using a Varian CG 3800 model (Varian, Inc., Palo Alto, CA, USA) equipped with a flame-ionization detector and a 5\% DEGS on Chromosorb WHP 80/100 mesh (6ft $2.0 \mathrm{~mm}$ ID) stainless steel packed column (Restek, Frankel Commerce of Analytic Instruments Ltd., SP, Brazil). Nitrogen was used as the carrier gas with a flow rate of $25 \mathrm{mLmin}^{-1}$. Temperature programming was performed. The column temperature was kept at $90^{\circ} \mathrm{C}$ for $3 \mathrm{~min}$, heated to $120^{\circ} \mathrm{C}$ at $25^{\circ} \mathrm{C} \min ^{-1}$ and kept constant for $10 \mathrm{~min}$. Then, the temperature was programmed at $25^{\circ} \mathrm{C} \min ^{-1}$ to $170^{\circ} \mathrm{C}$ and kept constant for $15 \mathrm{~min}$. The temperatures of the injector and detector were set at $250^{\circ} \mathrm{C}$. Data collection and analyses were performed using the software Galaxie Chromatography Data System version 1.9. Calibration curves were constructed with standard ethyl esters (ethyl linoleate, oleate, palmitate, stearate, myristate, laurate, caproate and caprylate) using hexanol as internal standard. The reaction yield was calculated by taking into account the mass of ester content obtained by GC analysis and the total theoretical ester mass based on the reaction molar ratio (Urioste et al., 2008).

\section{Purification of Biodiesel}

At the end of the reaction, the lipase preparation was separated from the reaction medium and the organic phase was washed twice with one volume of water to remove the remaining ethanol and free glycerol formed as a by-product. Residual water was removed by rotary evaporation and the final fatty acid ethyl ester product obtained.

\section{Viscosity Determination}

The absolute viscosity of biodiesel was determined with a LVDV-II cone and plate spindle Brookfield viscosimeter (Brookfield Viscometers Ltd, England) using a CP 42 cone. A circulating water bath was used to maintain the temperature in each analysis at $40^{\circ} \mathrm{C}$ for biodiesel samples and $50^{\circ} \mathrm{C}$ for beef tallow with an accuracy of $0.1^{\circ} \mathrm{C}$. The shear stress measurements were taken as a function of shear rate and the dynamic viscosity was determined as the slope constant. Samples of $0.5 \mathrm{~mL}$ were used and the measurements were replicated three times.

\section{Thermal Study}

TG curves for beef tallow and biodiesel samples were recorded using a thermal balance (Shimadzu TGA-50 - Thermogravimetric Analyzer). A dynamic method was used, at a heating rate of $10{ }^{\circ} \mathrm{C} . \mathrm{min}^{-1}$. The initial sample mass was $10.00 \pm 0.5 \mathrm{mg}$, in nitrogen atmosphere with a flow rate of $50 \mathrm{~mL}$. $\mathrm{min}^{-1}$, in the $25-1000^{\circ} \mathrm{C}$ temperature range (Monteiro et al., 2008).

\section{Infrared Spectroscopy}

Infrared spectroscopy was used to investigate the compounds formed by the transesterification reaction of the beef tallow. The IR spectra were recorded in a Perkin Elmer Spectrum GX, spectrometer, using $\mathrm{KBr}$ pellets, in the range of $4000-400 \mathrm{~cm}^{-1}$.

\section{Proton Nuclear Magnetic Resonance ( ${ }^{1}$ H NMR)}

The ${ }^{1} \mathrm{H}$ NMR spectroscopy was performed on a Varian Mercury spectrometer operating at $300 \mathrm{MHz}$. Approximately $120 \mathrm{mg}$ of sample were dissolved in $0.6 \mathrm{~mL}$ of $\mathrm{CDCl}_{3}$ that contained $0.03 \%$ tetramethylsilane, and the resulting solutions were placed in a $5 \mathrm{~mm}$ diameter NMR tube.

\section{RESULTS AND DISCUSSION}

\section{Enzymatic Synthesis of Beef Tallow with Ethanol Using Immobilized Lipase}

Biodiesel synthesis was carried out as described in the Materials and Methods using microbial lipases from B. cepacia (PS) and P. fluorescens (AK) 
immobilized on $\mathrm{SiO}_{2}$-PVA. In a typical reaction, a mixture with a beef tallow-to-ethanol molar ratio of 1:9 was incubated at $45^{\circ} \mathrm{C}$ with 400 units of activity of each immobilized derivative.

The reaction was monitored by quantifying the major constituents by GC analysis as displayed in Figures 1 (a-b). Transesterification yields and productivities for the tested lipase preparations, as well as the corresponding viscosity of the biodiesel samples, are shown in Table 1.

These figures indicate similarity of the reaction rates, attaining in both cases equilibrium at $48 \mathrm{~h}$. The profile of the esters formed was similar for the immobilized derivatives, showing selectivity of lipases PS and AK regarding the fatty acids present in beef tallow. The total saturated and unsaturated fatty acid contents of beef tallow were $60 \%$ and $40 \%$, respectively. The major constituents identified in the

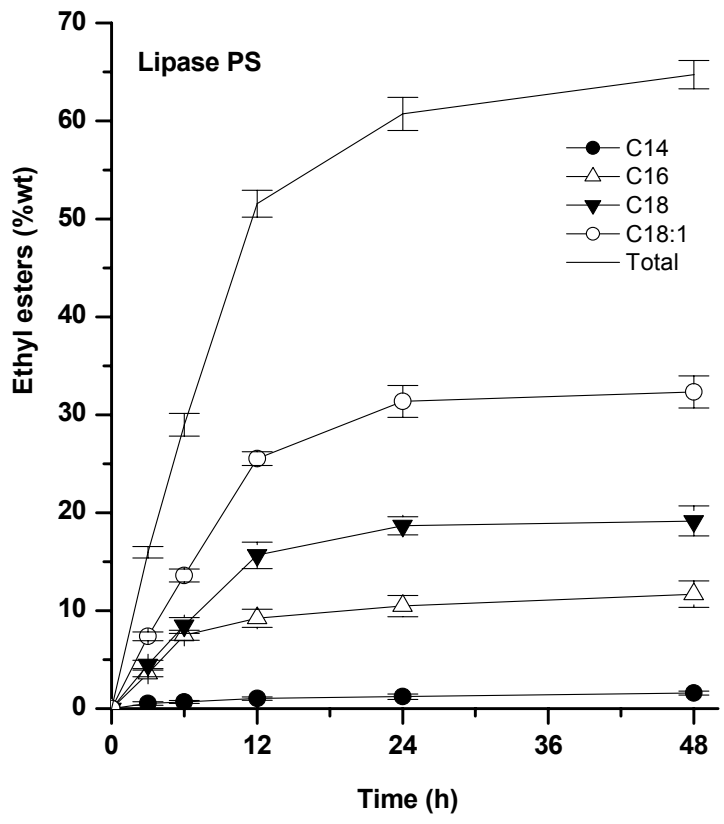

(a) reaction medium were ethyl oleate, stearate and palmitate in accordance with the beef tallow fatty acid composition. The similarity of the ethyl ester profile may be explained by the lipase structures taking into consideration the N-terminal amino acid sequences and molecular weights (Kojima and Shimizu, 2003; Burgess and Jennings, 1991). This may explain the slightly higher transesterification yield attained in the reaction mediated by PS lipase. In agreement with these results, both lipases showed high activity towards the transesterification of beef tallow with ethanol, although a slightly higher yield was attained with PS lipase, attaining in $48 \mathrm{~h}$ concentrations in esters of $64.74 \pm 1.45 \% \mathrm{wt}$, corresponding to a yield of $96.25 \%$. To confirm these results, the transesterified samples were submitted to further analysis, including a rheological study (Table 1), FTIR, termogravimetry and ${ }^{1} \mathrm{H}$ NMR (Monteiro et al., 2008).

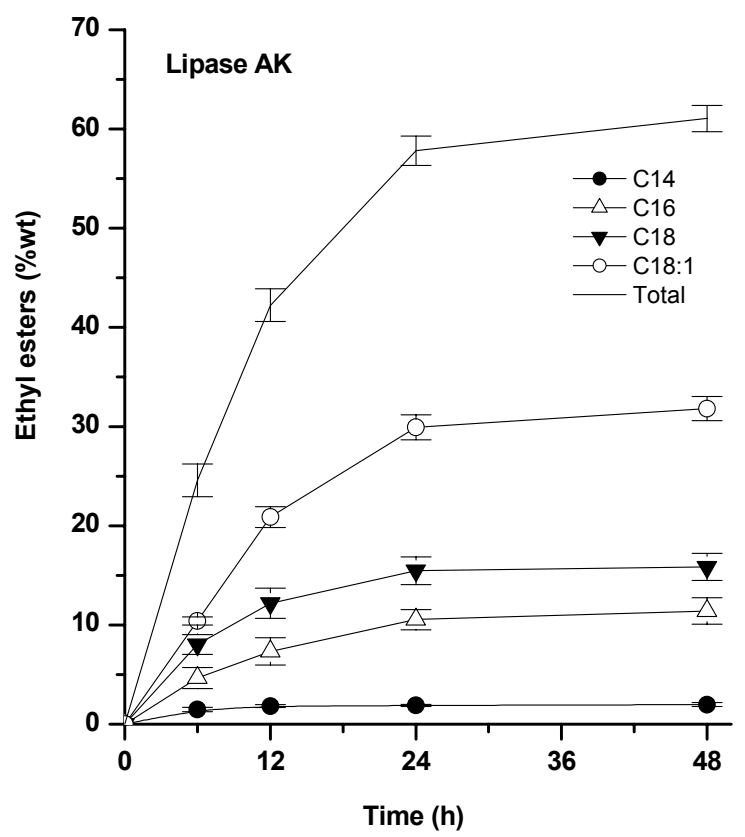

(b)

Figure 1: Profiles for ethyl esters formation in the transesterification reaction of beef tallow with ethanol catalyzed by lipases from Burkholderia cepacia (PS) and Pseudomonas fluorescens (AK) immobilized on epoxy $\mathrm{SiO}_{2}$-PVA. Reactions were performed at $45^{\circ} \mathrm{C}$, using a beef tallow-to-ethanol molar ratio of 1:9 under 150 rpm mechanical agitation. Symbols: C14 (•); C16 ( $\triangle)$; C18 ( $\mathbf{v})$; C18:1 (O); full line (total esters).

Table 1: Performance of the immobilized Burkholderia cepacia and Pseudomonas fluorescens lipases in the beef tallow ethanolysis reaction

\begin{tabular}{|l|c|c|c|}
\hline Lipase & $\begin{array}{c}\text { Yield } \\
\mathbf{( \% )}\end{array}$ & $\begin{array}{c}\text { Productivity } \\
\left(\mathbf{m g ~ e t h y l ~ e s t e r s ~} \mathbf{~ g}^{\mathbf{1}} \mathbf{.} \mathbf{~ h}^{\mathbf{1}} \mathbf{)}\right.\end{array}$ & $\begin{array}{c}\text { Absolute Viscosity } \\
(\mathbf{c P})\end{array}$ \\
\hline B. cepacia (PS) & $96.25 \pm 1.45$ & 13.48 & 5.89 \\
P. fluorescens (AK) & $91.34 \pm 1.32$ & 12.72 & 7.34 \\
\hline
\end{tabular}

data corresponding to $48 \mathrm{~h}$ reaction. 


\section{Biodiesel Analysis}

Viscosity is an important property of biodiesel since it affects the fluidity of the fuel and the operation of fuel injection equipment. High viscosity leads to poorer atomization of the fuel spray and less accurate operation of fuel injectors. The viscosity values for lipid raw materials are between 28 and $52 \mathrm{cP}$ and sharply decreased upon transesterification, as demonstrated by Moreira et al. (2007). Therefore, the viscosity value can also be used as a parameter to monitor the transesterification reaction, confirming the conversion of the triglycerides into esters (Moreira et al., 2007) by following the viscosity reduction of the reaction medium. Table 1 displays values found for the viscosity of the biodiesel samples obtained with lipases PS (5.89) and AK (7.34). Both biodiesel samples showed consistent reduction of the viscosity in comparison of beef tallow $(43.82 \mathrm{cP})$. However, the biodiesel sample obtained in the reaction catalyzed by lipase PS provided the lowest viscosity value, which also confirmed the highest conversion of triglycerides into ethyl esters as determined by GC analysis.

Another technique for monitoring the transesterification of oils/fats is IR spectroscopy, due to its many advantages. It is non-destructive, very reliable and allows direct and fast determination of several properties without sample pretreatment Several methodologies have been developed based on the use of multivariate analysis applied to near infrared spectroscopy (NIR) and Fourier-transform infrared spectroscopy (FTIR) (Monteiro et al., 2008; Soares et al., 2011). Here no attempt was made to quantify the transesterification yields using this methodology. Instead, the biodiesel quality was assessed by FTIR and correlated with other analytical data in order to crosscheck the results.

Figure 2 displays the infrared spectra for beef tallow and biodiesel samples, which reflect the high chemical similarity that exists between triglycerides and ethyl esters.

The beef tallow sample showed a spectrum with vibrational bands related to the triglycerides at 1159 and $1744 \mathrm{~cm}^{-1}$, respectively, attributed to the stretching of $\mathrm{C}-\mathrm{O}$ and $\mathrm{C}=\mathrm{O}$ groups. It also presented absorption in the wavelength range from 2848 and $2917 \mathrm{~cm}^{-1}$ for $\mathrm{C}-\mathrm{H}$ bond stretching. The presence of a band ascribed to the group $\left(\mathrm{CH}_{2}\right)_{\mathrm{n}}$ is observed at $723 \mathrm{~cm}^{-1}$.

The infrared spectra for biodiesel samples were very similar, showing absorption bands in the regions $1750-1735 \mathrm{~cm}^{-1}$ (ester $\mathrm{C}=\mathrm{O}$ axial deformation), $1200 \mathrm{~cm}^{-1}$ related to the ester $\mathrm{C}-\mathrm{O}$ axial deformation and $723 \mathrm{~cm}^{-1}$ related to the group $\left(\mathrm{CH}_{2}\right)_{\mathrm{n}}$. This behavior is similar to that reported for biodiesel samples obtained from different lipid raw materials (Soares et al., 2011).

The absence of a broad band in the $3100-3500 \mathrm{~cm}^{-1}$ region related to axial deformation characteristic of $\mathrm{OH}$ groups suggests that biodiesel samples had low water contents as can also be verified by other techniques, including the thermogravimetric analyses discussed in the following paragraphs. This methodology was selected here since it allows study of the thermal behavior of organic materials and the kinetics of the thermal decomposition reactions of different liquid fuels (Santos et al. 2007; Miranda et al., 2008; Chand et al., 2009; Araujo et al., 2010).

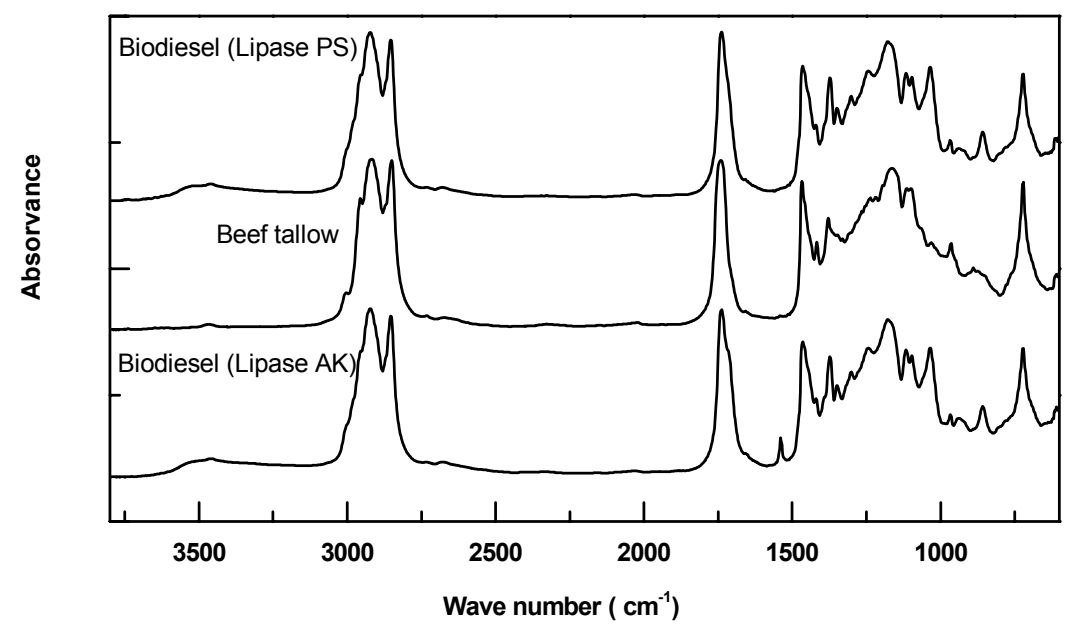

Figure 2: IR spectra for beef tallow and biodiesel samples obtained in the transesterification reactions using the lipases PS and AK immobilized on epoxy $\mathrm{SiO}_{2}$-PVA. 
Thermogravimetric analysis generates a thermal decomposition curve that gives the degradation stages of the samples as a function of temperature or time (Miranda et al., 2008). Through this analysis, it is possible to establish parameters of thermal stability of the beef tallow and biodiesel samples. In addition, thermogravimetric analysis can be used as a fast, low cost, screening method for biodiesel conversion, as proposed by Chand et al. (2009). Therefore, this technique can be used not only to determine biodiesel product quality, but also to monitor the transesterification progress.

Figure 3 shows the TG curves of beef tallow and biodiesel samples obtained in the transesterification reactions using the lipases PS and AK. The temperatures and the corresponding mass losses are exhibited in Table 2.

Beef tallow was thermally stable up to $210^{\circ} \mathrm{C}$, showing only one stage of thermal degradation between $210-560^{\circ} \mathrm{C}$, with $99 \%$ mass loss that corresponds to the thermal decomposition of triglycerides.
The biodiesel sample obtained with lipase PS revealed only one degradation step in the temperature range from $128-400^{\circ} \mathrm{C}$, with a mass loss of $98 \%$ associated with the evaporation and/or degradation of the ethyl esters. This indicates the absence of triglycerides in the biodiesel sample, confirming the high conversion attained with this lipase source (Table 2).

In relation to the biodiesel sample prepared with the lipase $\mathrm{AK}$, three thermal degradation stages were observed. The initial temperature of thermal decomposition of biodiesel was lower than the oil itself, corroborating the decrease of viscosity due to the transesterification reaction as displayed in Table 1 . The first occurred in the temperature range from $26-56^{\circ} \mathrm{C}$, with a mass loss of $4 \%$, probably due to traces of ethanol not completely removed in the evaporation step. The second, in the temperature range from $124-280^{\circ} \mathrm{C}$, with a mass loss of $86 \%$, reflects the decomposition of ethyl esters. The third took place in the temperature range from $280-365^{\circ} \mathrm{C}$, with a mass loss of $10 \%$, due to mono, di and triglycerides not converted into esters.

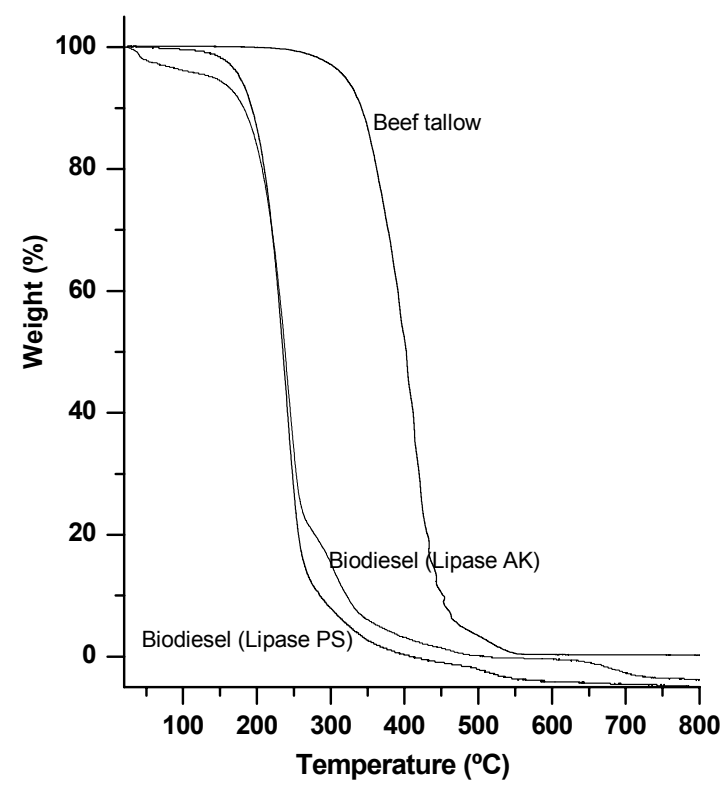

Figure 3: TG curves of beef tallow and biodiesel samples obtained in the transesterification reactions using the lipases PS and AK immobilized on epoxy $\mathrm{SiO}_{2}$-PVA.

Table 2: Representative DTG data for beef tallow in natura and biodiesel samples obtained by the transesterification reactions catalyzed by PS and AK lipases immobilized on epoxy $\mathrm{SiO}_{2}-\mathrm{PVA}$

\begin{tabular}{|l|c|c|c|}
\hline Sample & Step & $\begin{array}{c}\text { Temperature range } \\
\left({ }^{\circ} \mathbf{C}\right)\end{array}$ & $\begin{array}{c}\triangle_{\text {mass }} \\
(\%)\end{array}$ \\
\hline Beef tallow & $1^{\text {st }}$ & $210-560$ & 99 \\
\hline Biodiesel (Lipase PS) & $1^{\text {st }}$ & $128-290$ & 98 \\
\hline \multirow{2}{*}{ Biodiesel (Lipase AK) } & $1^{\text {st }}$ & $26-56$ & 4 \\
& $2^{\text {nd }}$ & $124-280$ & 86 \\
\end{tabular}


In agreement with the results, it was verified that the lipase PS produced a product with a better set of properties for use as a biofuel. These results are similar to those described by Araujo et al. (2010) using biodiesel samples obtained from beef tallow and methanol through a chemical route $(\mathrm{KOH})$. A mass loss of $96 \%$ regarding decomposition of methyl esters was observed in the temperature range from $195-312^{\circ} \mathrm{C}$. Additionally, at $367^{\circ} \mathrm{C}$ there was a mass loss of $3 \%$ reflecting the thermal decomposition of mono, di and triglycerides residues.

Further information on the quality of the biodiesel samples was obtained by ${ }^{1} \mathrm{H}$ NMR analysis, as displayed in Figure 4. These groups are assigned as follows (Miyake et al., 1998): a) olefinic protons and one methine proton in the glyceryl group; b) four methylene protons in the glyceryl group; c) six $\alpha$ methylene protons adjacent to carbonyl carbon; d) allyl methylene protons; e) six $\beta$-methylene protons from the carbonyl carbon; f) methylene protons on saturated carbon atoms; g) terminal methyl protons of saturated, monounsaturated, and $n-6$ polyunsaturated fatty acids.
As can be seen in Figure 4, mutiplets at 4.10-4.32 ppm (signal b) attributed to the protons on the 1 and 3 carbon atoms of the glyceryl group were totally absent due to the conversion of triglycerides into ethyl esters, which also shows the formation of ethyl esters via the quartet at 4 to $4.2 \mathrm{ppm}$. These spectra provided evidence that complete transesterification of beef tallow had occurred.

Taking into consideration this data, it was possible to conclude that the biodiesel obtained by using the lipase PS presented a better set of properties when compared with the biodiesel obtained with the lipase AK. This result is similar to those obtained by Hsu et al. (2001), who also demonstrated that this same lipase was the most efficient in the transesterification of beef tallow with ethanol, attaining 95\% conversion in $24 \mathrm{~h}$. In another work (Nelson et al., 1996) under somewhat different conditions (using hexane as solvent), this lipase source was also found to be the most suitable catalyst for converting beef tallow into methyl esters.
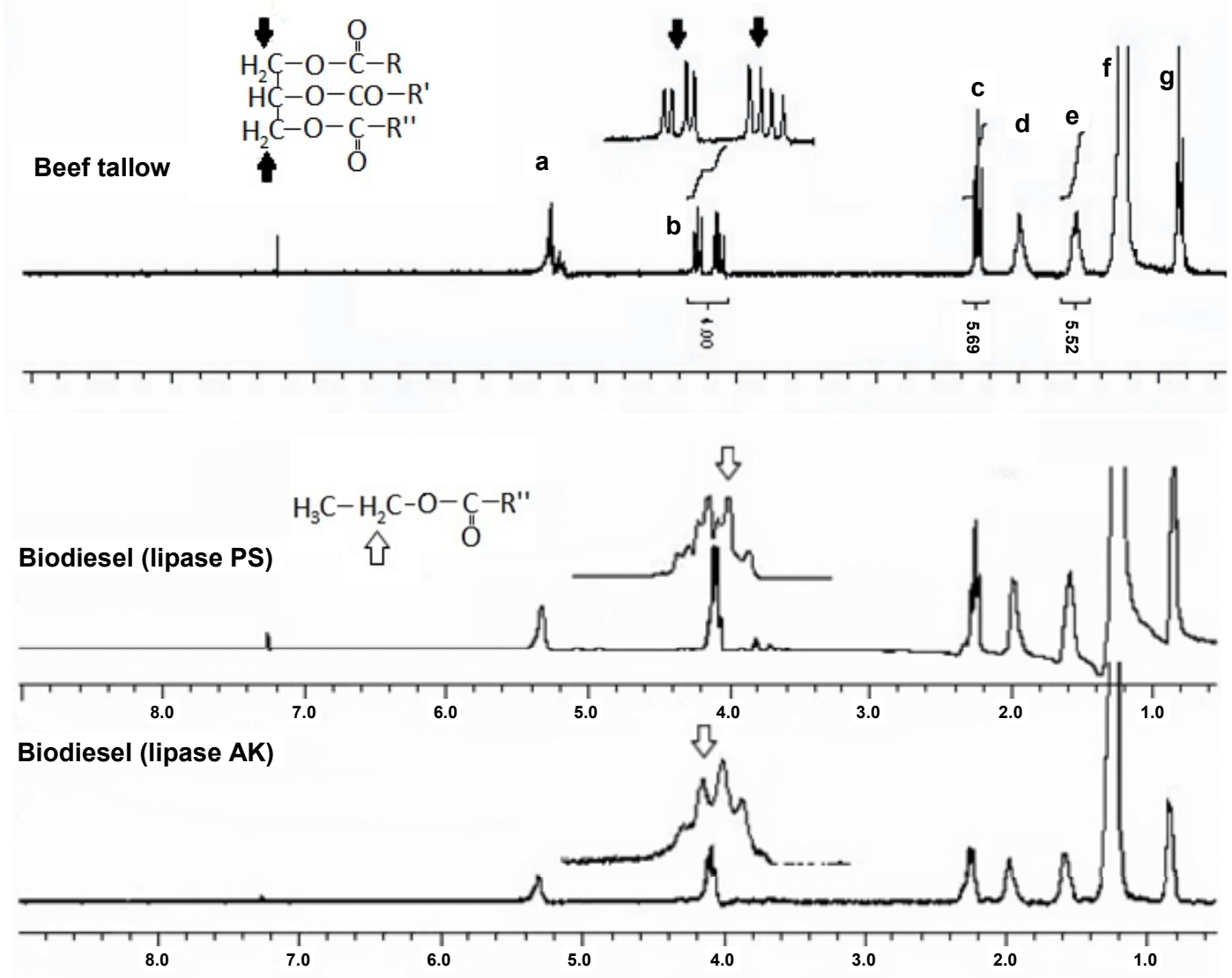

Figure 4: ${ }^{1} \mathrm{H}$ NMR spectra for beef tallow and biodiesel samples obtained with lipases PS and AK immobilized on epoxy $\mathrm{SiO}_{2}$-PVA. 


\section{CONCLUSION}

The microbial lipases: Burkholderia cepacia and Pseudomonas fluorencenses immobilized on a $\mathrm{SiO}_{2}$-PVA matrix showed capacity for catalyzing ethanolysis reaction of beef tallow with ethanol, attaining high conversion in $48 \mathrm{~h}$. However, the highest yield (96.25\%) was achieved with PS lipase.

Analytical techniques, including, infrared spectroscopy, viscosimetry, thermogravimetry and ${ }^{1} \mathrm{H}$ NMR spectroscopy were shown to be practical tools to aid the selection of the most suitable lipase source to mediate the synthesis of biodiesel. Based on the results described in this work, it was possible to infer that the biodiesel obtained with the lipase PS presented a better set of properties for use as biofuel. Work is still on-going to decrease the reaction time in order to turn this enzymatic route competitive with conventional chemical catalysis.

\section{ACKNOWLEDGMENTS}

The authors wish to thank Dr. Jayne C. S. Barboza for helping in the FTIR and ${ }^{1} \mathrm{H}$ NMR interpretations. This work was financially supported by the Conselho Nacional de Desenvolvimento Científico e Tecnológico (CNPq) and the Fundação de Auxílio a Pesquisa do Estado de São Paulo (FAPESP).

\section{REFERENCES}

Araujo, B. Q., Nunes, R. C. R., Moura, C. V. R., Moura, E. M., Cito, M. G. L., Santos, R. J., Synthesis and characterization of beef tallow biodiesel. Energy and Fuels, v. 24, p. 4476-4480 (2010).

Bouaid, A., Martinez, M., Aracil, J., Production of biodiesel from bioethanol and Brassica carinata oil: Oxidation stability study. Bioresource Technology, v. 100, p. 2234-2239 (2009).

Burgess, K., Jennings, L. D., Enantioselective esterifications of unsaturated alcohols mediated by a lipase prepared from Pseudomonas sp. Journal of the American Chemical Society, v. 113, p. 6129-6139 (1991).

Chand, P., Reddy, Ch. V., Verkade, J. G., Wang, T., Grewell, D., Thermogravimetric quantification of biodiesel produced via alkali catalyzed transesterification of soybean oil. Energy and Fuels, v. 23, p. 989-992 (2009).

Da Cunha, M. E., Krause, L. C., Moraes, M. S. A., Faccini, C. S., Jacques, R. A., Almeida, S. R.,
Rodrigues, M. R. A., Camarão, E. B., Beef tallow biodiesel produced in a pilot scale. Fuel Processing Technology, v. 90, p. 570-575 (2009).

Da Rós, P. C. M., Silva, G. A. M., Mendes, A. A., Santos, J. C. De Castro, H. F., Evaluation of the catalytic properties of Burkholderia cepacia lipase immobilized on non-commercial matrices to be used in biodiesel synthesis from different feedstocks. Bioresource Technology, v. 101, p. 5508-5516 (2010).

Duarte, A., O peso da matéria prima. Biodieselbr, v. 9, p. 19 (2009).

Freitas, L., Da Rós, P. C. M., Santos, J. C., De Castro, H. F., An integrated approach to produce biodiesel and monoglycerides by enzymatic interestification of babassu oil (Orbinya sp). Process Biochemistry, v. 44, p. 1068-1074 (2009).

Ghaly, A. E., Dave, D., Brooks, M. S., Budge, S., Production of biodiesel by enzymatic transesterification: Review. American Journal of Biochemistry and Biotechnology, v. 6, n. 2, p.5476 (2010).

Haas, M. J., Improving the economics of biodiesel production through the use of low value lipids as feedstocks: Vegetable oil soapstock. Fuel Processing Technology, v. 86, p. 1087-1096 (2005).

Helwani, Z., Othman, M. R., Aziz, N., Fernando, W. J. N., Kim, J., Technologies for production of biodiesel focusing on green catalytic techniques: A review. Fuel Processing Technology, v. 90, p. 1502-1514 (2009).

Hsu, A., Jones, K., Marmer, W. N., Foglia, T. A., Production of alkyl esters from tallow and grease using lipase immobilized in a phyllosilicate solgel. Journal of the American Oil Chemists' Society, v. 78, p. 585-588 (2001).

Kiss, F. E., Jovanović, M., Bosković, G. C., Economic and ecological aspects of biodiesel production over homogeneous and heterogeneous catalysts. Fuel Processing Technology, v. 91, p. 1316-1320 (2010).

Knothe, G., Gerpen, J. V., Krahl, J., Ramos, L. P., Manual do Biodiesel. $1^{a}$ ed., São Paulo: Edgard Blucher (2006).

Kojima, Y., Shimizu, S., Purification and characterization of the lipase from Pseudomonas fluorescens HU380. Journal of Bioscience and Bioenginnering, v. 96, p. 219-226 (2003).

Miranda, T., Esteban, A., Rojas, S., Montero, I., Ruiz, A., Combustion analysis of different olive residues. International Journal of Molecular Science, v. 9, p. 512-525 (2008). 
Miyake, Y., Yokomizo, K., Matsuzaki, N., Determination of unsaturated fatty acid composition by high-resolution nuclear magnetic resonance spectroscopy. Journal of the American Oil Chemist's Society, v. 75, p. 1091-1094 (1998).

Monteiro, M. R., Ambrozini, A. R. P., Lião, L. M., Ferreira, A. G., Critical review on analytical methods for biodiesel characterization. Talanta, $\mathrm{v}$. 77, p. 593-605 (2008).

Moreira, A. B. R., Perez, V. H., Zanin, G. M., De Castro, H. F., Biodiesel synthesis by enzymatic transesterification of palm oil with ethanol using lipases from several sources immobilized on silica-PVA composite. Energy and Fuels, v. 21, p. 3689-3694 (2007).

Muthu, H., SathyaSelvabala, V., Varathachary, T. K., Kirupha Selvaraj, D., Nandagopal, J. and Subramanian, S., Synthesis of biodiesel from neem oil using sulfated zirconia via transesterification. Brazilian Journal of Chemical Engineering, v. 27, n. 4, p. 601- 608 (2010).

Nelson, L. A., Foglia, T. A., Marmer, W. A., Lipase -catalyzed production of biodiesel. Journal of the American Oil Chemists' Society, v. 73, p.11911195 (1996).

Pinto, A. C., Guarieiro, L. L. N., Michelle, J. C. R., Ribeiro, N. M., Torres, E. A., Lopes, W. A., Pereira, P.A.P., Andrade, B. A. Biodiesel: An overview. Journal of Brazilian Chemical Society, v. 16, p. 1313-1330 (2005).

Ranganathan, S. V., Narasimhan, S. L., Muthukumar, K., An overview of enzymatic production of biodiesel. Bioresource Technology, v. 99, p. 3975-3981 (2008).

Santos, J. C., Paula, A. V., Nunes, G. F. M., De
Castro, H. F., Pseudomonas fluorescens lipase immobilization on polysiloxane-polyvinyl alcohol composite chemically modified with epichlorohydrin. Journal of Molecular Catalysis. B Enzymatic. v. 52-53, p. 49-57 (2008).

Santos, N. A., Tavares, M. L. A., Rosenhaim, R., Silva, F. C., Fernandes, J. V. J., Santos, I. M. G., Souza, A. G., Thermogravimetric and calorimetric evaluation of babassu biodiesel obtained by the methanol route. Journal of Thermal Analytical Calorimetry. v. 87, p. 649-652 (2007).

Soares, C. M. F., Castro, H. F., Moraes, F. F., Zanin, G. M., Characterization and utilization of Candida rugosa lipase immobilized on controlled pore silica. Applied Biochemistry and Biotechnology, v. 77-9, p. 745-757 (1999).

Soares, I. P., Rezende, T. F., Pereira, R. C. C., Santos, C. G., Fortes, I. C. P., Determination of biodiesel adulteration with raw vegetable oil from ATR-FTIR data using chemometric tools. Journal of the Brazilian Chemical Society, v. 22, n. 7, 1229-1235 (2011).

Tan, T., Lu, J., Nie, K., Deng, L., Wang, F., Biodiesel production with immobilized lipase: A review. Biotechnology Advances, v. 28, n. 5, p. 628-634 (2010).

Urioste, D., Castro, M. B. A., Biaggio, F. C., De Castro, H. F., Síntese de padrões cromatográficos e estabelecimento de método para dosagem da composição de ésteres de ácidos graxos presentes no biodiesel a partir do óleo de babaçu. Química Nova, v. 31, n. 2, p. 407-412 (2008).

Vasudevan, P. T., Briggs, M., Biodiesel production Current state of the art and challenges. Journal of Industrial Microbiology and Biotechnology, v. 35, p. 421-430 (2008). 